\title{
International Climate Technology Strategies
}

Forthcoming in Climate Change Policy Beyond Kyoto, J. Aldy and R. Stavins, eds. Cambridge, UK: Cambridge University Press.

\section{Richard G. Newell}

Duke University

National Bureau of Economic Research

Resources for the Future

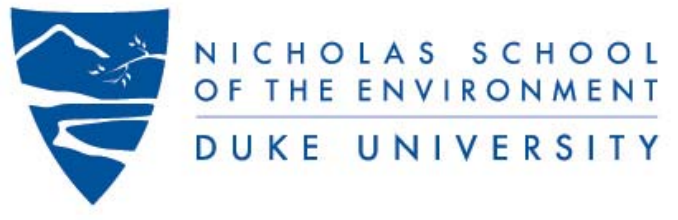

Box 90227

Durham, NC 27708

http://www.nicholas.duke.edu/people/faculty/newell.html 


\title{
International Climate Technology Strategies
}

\author{
Richard G. Newell
}

\begin{abstract}
This paper considers opportunities for improved and expanded international development and transfer of climate technologies. It characterizes the economic scale of the climate technology challenge, and it reviews the pattern of public and private $R \& D$ and the rationale for $R \& D$ policies within the global innovation system. The paper clarifies the importance of options for inducing technology market demand through domestic GHG pricing, international trade, and international development assistance. It then turns to upstream innovation strategies, including international coordination and funding of climate technology R\&D, and knowledge transfer through intellectual property. The paper concludes that a successful international effort to accelerate and then sustain the rate of development and transfer of GHG mitigation technologies must harness a diverse set of markets and institutions beyond those explicitly related to climate, to include those for energy, trade, development, and intellectual property.
\end{abstract}

Key Words: international; climate change; innovation; R\&D; technology; policy JEL Classification Numbers: Q28, D81, C68 


\section{Contents}

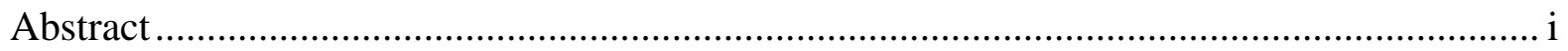

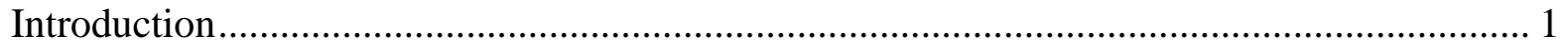

The climate change technology challenge ……………........................................................ 3

Economic scale of the technology challenge ................................................................... 4

Importance of advanced technology for lowering costs and expanding options ................. 5

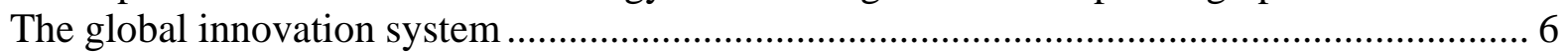

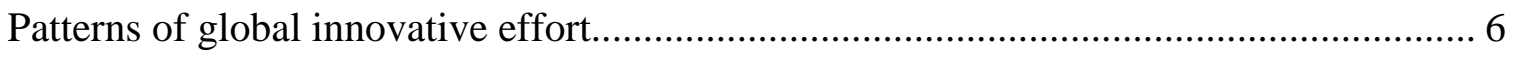

Innovation market problems and policy strategies …………………………………...... 7

Technology development and transfer through market demand................................................ 9

GHG emission pricing through domestic emission commitments ..................................... 9

Technology transfer through international trade and development assistance .................. 13

Complementary upstream technology innovation strategies .................................................. 17

International coordination and augmentation of climate mitigation R\&D ...................... 17

Knowledge transfer through intellectual property .................................................... 26

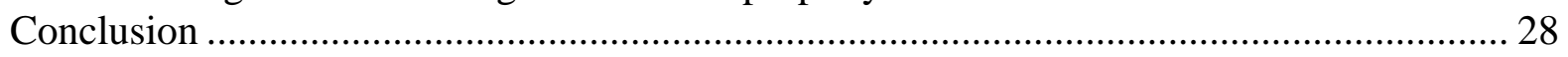

Figures and Tables ....................................................................................................... 31

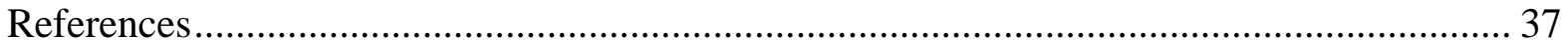




\title{
International Climate Technology Strategies
}

\author{
Richard G. Newell*
}

\section{Introduction}

There is widespread agreement that achieving the very substantial reductions in greenhouse gas (GHG) emissions necessary to stabilize atmospheric carbon dioxide $\left(\mathrm{CO}_{2}\right)$ concentrations at 450 to 550 parts per million (ppm) will require innovation and large-scale adoption of GHG-reducing technologies throughout the global energy system (IPCC 2007). The set of necessary technologies includes those for increased energy efficiency, renewable energy, nuclear power, and $\mathrm{CO}_{2}$ capture and storage. Alongside strategies aimed at reducing GHG emissions — such as emission targets in an international context or domestic GHG cap-and-trade systems or taxes-much discussion has therefore focused on policies that also target technology directly, including research and development (R\&D) ${ }^{1}$ activities and technology-specific mandates and incentives. The associated policy debate is not so much over the importance of new technology per se in solving the climate problem, but rather over what the most effective policies and institutions are for achieving the dramatic technological changes necessary to stabilize GHG concentrations.

The scale of the system to be reoriented is immense. The International Energy Agency (IEA), in its most recent assessment of energy investment, projects that about \$22 trillion of investment in energy-supply infrastructure will be needed over the 2006-2030 period, or almost

\footnotetext{
* Newell is the Gendell Associate Professor of Energy and Environmental Economics at the Nicholas School of Environment, Duke University, a Research Associate at the National Bureau of Economic Research, and a University Fellow at Resources for the Future. The paper benefited from comments by Joseph Aldy, an anonymous referee, and participants at the workshop of the Harvard Project on International Climate Agreements (Venice, Italy, May 2008), as well as from conversations with Bob Marlay, Arti Rai, Jerome Reichman, and Jonathan Wiener.

${ }^{1}$ For simplicity the term "R\&D" is intended to include initial "first-of-a-kind" demonstration projects focused on generating new knowledge.
} 
$\$ 900$ billion annually, on average (IEA 2007b). Note that this does not include expenditures on energy demand-side technologies (e.g., transportation, appliances, and equipment) which will measure in the trillions of dollars each year. Relative to this baseline investment, the Secretariat of the United Nations Framework Convention on Climate Change (UNFCCC) estimates that an additional \$200 billion in global investment and financial flows will be required annually by 2030 just to return GHG emissions to current levels (UNFCCC 2007a).

What are the most important international and domestic actions necessary to technologically alter energy systems in a direction that can achieve GHG stabilization targets while also meeting other societal goals? Growing attention has turned to the possible role of international technology-oriented agreements as part of the architecture of an international climate change policy (de Coninck, et al. 2008). Specific activities under such agreements could include knowledge sharing and coordination, joint R\&D, technology transfer, and technology deployment mandates, standards, or incentives.

Interest in these efforts is attributable to a number of factors, generally related to the idea that if we can lower the costs of mitigation technologies, the likelihood that countries will implement significant GHG reductions will be higher. Agreements to further R\&D can increase the international exchange of scientific and technical information while also improving the costeffectiveness of R\&D through cost sharing and reduced duplication of effort. Provisions for technology transfer, on the other hand, originate primarily in the need to help developing countries follow a less GHG-intensive development path by providing access to climate-friendly technologies and the funding to cover their additional cost. As such, technology transfer efforts can help to increase incentives for developing-country participation in international climate agreements and at the same time advance goals beyond global climate mitigation (e.g., economic development, local air quality improvement, energy security). The Bali Action Plan therefore identified technology development and transfer as one of five central issues for consideration 
during development of a post-2012 international climate policy agreement (alongside a longterm emissions goal and actions on mitigation, adaptation, and financing) (UNFCCC 2008).

This paper considers opportunities for improved and expanded international technology development and transfer strategies within the broader context of international agreements and institutions for climate, energy, trade, development, and intellectual property. The next section characterizes the economic scale of the climate technology challenge, while subsequent sections review the pattern of public and private $R \& D$ and the economic rationales for $R \& D$ policies within the global innovation system; clarify the importance of options for inducing technology market demand through domestic GHG pricing, international trade, and international development assistance; and discuss upstream innovation strategies, including international coordination and funding of climate technology R\&D, and knowledge transfer through intellectual property. A concluding section summarizes the main international technology issues and actions identified for consideration within the post-2012 dialogue.

\section{The climate change technology challenge}

Since its adoption in 1992, the UNFCCC has been ratified by virtually all the world's 190-plus countries. The treaty’s principle objective is “stabilization of greenhouse gas concentrations in the atmosphere at a level that would prevent dangerous anthropogenic interference with the climate system." Although there is much debate about what level of GHG concentrations would prevent dangerous anthropogenic interference, one thing is clear: Stabilizing GHG concentrations at any level implies eventually reducing net GHG emissions to near zero.

While the idea of balancing the atmospheric GHG stock by reducing the net GHG flow to zero is simple enough, the technological reality of what it will take to do this is far from simple. Currently, 69 percent of global anthropogenic GHG emissions come from fossil fuels such as oil, coal, and natural gas, which together satisfy 81 percent of global energy demand (IEA 2007b, 
2007d). The remainder of global energy is supplied by renewable energy (13 percent) and nuclear power (6 percent) (IEA 2007b).

Stabilizing GHG concentrations therefore requires large-scale and widespread substitution toward energy technologies with low to zero net GHG emissions throughout the global energy system. However, under existing policies and expected market trends, the IEA forecasts that world energy consumption will grow 55 percent and energy-related $\mathrm{CO}_{2}$ emissions 57 percent between 2005 and 2030, with the fossil-fuel share rising slightly from 81 to 82 percent (IEA 2007b). Although there is substantial uncertainty over longer timeframes, recent estimates suggest that, without additional policy actions, global annual $\mathrm{CO}_{2}$ emissions will increase by a factor of about three by the end of this century (Weyant et al. 2006; Fisher et al. 2007; Clark et al. 2007). These and other forecasts underscore the fact that the energy-economic system has a tremendous predisposition toward fossil-fuel-based technologies and would require substantial domestic and international policy actions to encourage change.

\section{Economic scale of the technology challenge}

To gauge, in economic terms, the magnitude of the innovation challenge presented by climate change, it is helpful to consider possible GHG emission targets and the projected costs of achieving these targets. These projected costs, most commonly measured in terms of reduced gross domestic product (GDP), indicate the scale of the benefit that could come from innovations that significantly reduce (or eliminate) the cost disadvantage of climate-friendly technologies relative to the competition. If such low-cost alternatives also made it feasible and desirable to undertake more significant reductions than otherwise would be taken, then there would also be a benefit from the further climate damages avoided. In fact, lowering the cost disadvantage of climate-friendly energy technologies relative to conventional fossil-fuel technologies—and thereby increasing the incentive to comply with international climate obligations—could play a major role in improving the long-run robustness of international frameworks (Barrett 2003). 
Many proposals, and most analyses, have centered on emission paths that are consistent with ultimate stabilization targets in the range of 450-550 ppm $\mathrm{CO}_{2}\left(530-670 \mathrm{ppm} \mathrm{CO}_{2}\right.$ equivalent, or $\mathrm{CO}_{2} \mathrm{e}$, if all GHGs are included). Modeling scenarios of cost-effective global climate mitigation policy suggest that, for targets in this range, the cost of GHG mitigation through 2050 is trillions or tens of trillions of US dollars of discounted GDP, or an annualized cost in the tens to hundreds of billions of dollars per year (Newell 2008). Longer-term total costs through 2100 are approximately double this amount. While these estimates are based on numerous economic and policy assumptions, they give a sense of the magnitude of the payoff from technology innovations that could significantly lower the cost of achieving various GHG emission goals.

Importance of advanced technology for lowering costs and expanding options

Many studies find that the availability and cost of advanced energy technologies plays a central role in determining the cost of achieving various GHG emission targets (IPCC 2007). Virtually all studies find that a cost-effective technology solution entails a mix of energy efficiency, low-GHG energy supply, as well as reductions in non- $\mathrm{CO}_{2}$ GHG emissions. Thus, R\&D to support the necessary transition to a low-carbon energy system must also be broadbased, covering a wide range of technological opportunities. For example, one study finds that if we were limited to technologies available in 2005, the present-value cost of achieving stabilization at 550 ppm $\mathrm{CO}_{2}$ would be more than $\$ 20$ trillion greater than the estimated cost taking into account expected developments in energy efficiency, hydrogen energy technologies, advanced bioenergy, and wind and solar technologies (Edmonds et al. 2007). The models used in these studies typically presume that the significant innovative efforts in $R \& D$, learning, and newtechnology diffusion needed to underpin these assumed technological improvements will be forthcoming.

Other studies have found that accelerated technology development offers the potential to dramatically reduce the costs of stabilization, with advanced technology scenarios reducing the 
cumulative costs of stabilization by 50 percent or more, which in turn yields economic benefits of hundreds of billions to trillions of dollars globally (Figure 1) (Newell 2008). While one might reasonably argue over the details of the modeling assumptions, these and other results demonstrate that technological advances have the potential to significantly reduce the costs of attaining societal goals for climate-change mitigation. The challenge is to structure policy to maximize the likelihood that we will harness these technological opportunities as effectively and efficiently as possible.

\section{The global innovation system}

Technological improvement through the creation and deployment of new product and process innovations is one of the most important underpinnings of economic development as well as of broader societal prosperity, including environmental protection. The complex set of institutions, markets, and governing processes that comprise this innovation system includes private firms and consortia, their products, their production processes, and the markets within which they operate; government research institutions and public policies; universities and colleges; and other non-profit research institutions (Figure 2).

\section{Patterns of global innovative effort}

Nations spend about \$1 trillion globally each year on R\&D, with over 95 percent occurring in the OECD countries, Russia, and China-and 80 percent in countries represented in the G8 (see Table 1). The focus here is on overall R\&D; private and public energy-related R\&D is discussed in subsequent sections. Although innovation activities are not limited to $R \& D, R \& D$ remains one of the few well-tracked indicators of innovative activity and is highly correlated with other indicators.

Industry is by far the largest player in R\&D effort, funding over 60 percent and performing almost 70 percent of R\&D globally in 2006 (the most recent year for which complete data are available). Industrial R\&D focuses on applied research and especially development, 
stimulated by market demand for technologically advanced products and processes. Government is the second largest funder of R\&D globally (30 percent). About half of government funding is transferred to universities, other non-profit research institutions, and industry, which perform the associated R\&D within a system of contracts, grants, and other arrangements. Government funding tends to focus more on basic and applied research.

In addition to creating new knowledge upon which further technological development can draw, university-based R\&D supports the production of young researchers. Most of these researchers eventually move into the private sector-thus they represent an important link within the overall innovation system. Ensuring a stream of scientists, engineers, and other research professionals trained in areas relevant to clean-energy technologies will be an important element in increasing the necessary innovative effort and moderating its cost. The capacity of a country’s workforce to absorb and apply new know-how and technology is also essential for development, and it is one of the main impediments to more rapid technology transfer to developing countries (World Bank 2008c). By supporting researchers and graduate students, public funding for research affects an economy’s capacity to generate and assimilate scientific advances, technology innovations, and productivity improvements. This linkage has made research funding a priority among many who are concerned about the long-term competitiveness of national economies and has led to increased support for expanded R\&D spending generally, including in the United States and the European Union. At an international level, programs that facilitate the international exchange of graduate students, post-docs, and more senior scholars in areas relevant to climate-mitigation research can help to expand human-capital-related spillovers.

\section{Innovation market problems and policy strategies}

The explanation for current R\&D patterns is well-known. The gains from innovative activity are in general difficult for firms to appropriate, as the benefits tend to "spill over" to other firms and customers, without full compensation. While positive knowledge spillover is a good thing — other things equal—it leads to a level of private investment in innovative effort that 
is too low from a broader societal perspective. Moreover, this problem tends to become greater the further up the innovative chain one goes: from development, to applied, and then to basic research (See Newell 2008, IEA 2008a). When confronted with limited resources, it is sensible for public funding to focus first and foremost on the part of the innovation problem that is least likely to be addressed adequately by the private sector. Overall, public funding for precommercial research therefore tends to receive widespread support among experts. In situations where there is a missing market for the technology — as is currently the case for GHG mitigation in much of the world-climate policy that places a price on emissions can serve as the most costeffective means of encouraging technology deployment. ${ }^{2}$

Technology demonstration projects occupy a middle ground between technology development and deployment. Arguments for public support of technology demonstration tend to point to the large expense; high degree of technical, market, and regulatory risk; and inability of private firms to capture the rewards from designing and constructing first-of-a-kind facilities (Newell 2007a). Most compelling, from an economic perspective, is the fact that there may be non-appropriable returns to knowledge generated in the process of undertaking first-of-a-kind demonstration projects. For example, knowledge gained through such projects can help improve the design of future technology, lower technical risks, and serve as a basis for well-designed regulations. On the other hand, caution is required because-despite good intentions - many of the most notable failures in government energy R\&D funding have been associated with largescale demonstration projects (Cohen and Noll 1991).

While experience suggests that it should not be the focus of climate-mitigation technology investments by the public sector, public support for a limited number of first-of-akind demonstration projects could be valuable, so long as the purpose is to generate substantial

\footnotetext{
${ }^{2}$ For a more complete discussion of the role and design of technology deployment policies see Newell (2007b) in a domestic context and de Coninck et al (2008) in an international context.
} 
new knowledge. Given the dominant role of coal in the energy systems of both industrialized and developing countries, demonstrating technologies for carbon capture and storage has particular salience at the international level. The 2008 G8 Hokkaido Summit Leaders Declaration, for example, supported the launch of twenty large-scale CCS demonstration projects globally by 2010. Approaches for coordinating such projects at an international level are considered in a later section of this chapter.

\section{Technology development and transfer through market demand}

GHG emission pricing through domestic emission commitments

There are many excellent treatments of the advantages of economy-wide, long-term, multi-gas, flexible emission policies that attach a cost to-or "put a price” on—GHGs. The Kyoto Protocol, the EU Emission Trading System, and the legislative proposals with the most traction in the United States have embraced this approach. Establishing a GHG emission price (through policies such as cap-and-trade or emission taxes) is essential from a technology perspective for two primary reasons. First, because the GHG price attaches a financial cost to GHGs and-just as people will consume less of something expensive than something given away for free-will induce households and firms to buy technologies with lower GHG emissions (a more efficient appliance, for example). Ideally, the GHG price is designed to encourage the adoption of the most cost-effective technologies for reducing emissions by sending a consistent financial signal to households and businesses across the economy.

The second reason the GHG price is essential from a technology perspective is because it creates a demand-driven, profit-based incentive for the private sector to invest effort in developing new, lower-cost climate-friendly innovations. Market-demand pull will encourage manufacturers to invest in R\&D and other innovative efforts to bring new lower-GHG technologies to market, just as they do for other products and processes (for surveys see Jaffe et al. 2003 and Popp et al. 2008). Members of the US Climate Action Partnership (USCAP 2007)— 
a coalition of major US companies and environmental organizations-agreed when they concluded that "the most efficient and powerful way to stimulate private investment in research, development, and deployment is to adopt policies establishing a market value for GHG emissions over the long term.”

National policies that encourage GHG mitigation will therefore play an essential role in stimulating demand for, and innovation in, necessary new technologies. Conveniently, the vast majority of innovative effort globally takes place in developed countries that are expected to take the most significant initial steps to mitigate GHG emissions. In addition, agreements for the removal of existing subsidies for fossil fuels and related technologies would further move the global energy system in a more climate-friendly direction, while at the same time having broader economic benefits (UNEP 2008).

International carbon markets-employing flexibility mechanisms such as international linkage of domestic emission programs, offsets, and the Clean Development Mechanismrepresent an important mechanism for financing emission reductions in developing countries, technology transfer, and cost-effective GHG mitigation. Depending on numerous assumptions, including assumptions about aggregate GHG targets as well as about burden sharing between developed and developing countries, international demand for emission credits from developing countries is estimated to total in the tens of billions of dollars up to about $\$ 100$ billion annually through 2050 (UNFCCC 2007a). To facilitate technology transfer and create incentives for technology development at a global level, international agreements and domestic policies should consider establishing clear rules and minimizing unnecessary barriers to the use of these market mechanisms.

Innovation generated by policies that establish a GHG emission price is sure to come from a wide array of businesses currently engaged in the development and use of energy producing and consuming technologies, especially in the provision of electricity and transportation services. It will also come from the agro-biotech sector (assuming there are 
incentives for biological sequestration), from companies that produce and consume other non$\mathrm{CO}_{2} \mathrm{GHGs}$ (e.g., chemical companies), and from less obvious sectors such as the information technology industry (e.g., in the context of energy management and conservation). Estimates suggest that private-sector investments in energy R\&D, however, have fallen significantly in real terms since peaking around 1980, in tandem with declines in energy prices and public energy R\&D spending. Nonetheless, while the trend appears to have been downward over this period, current private-sector R\&D investments relevant to energy technology are extremely difficult to assess, and these estimates provide a poor indication of the overall level of private-sector R\&D investment that could and likely will be brought to bear on the climate technology challenge (Newell 2008).

In fact, many of the industrial sectors and individual companies that are likely to be most engaged in creating the innovations necessary to reduce GHG emissions have substantial R\&D capacity. Given expected levels of energy investment over the next several decades, and assuming the level of associated private R\&D investment is measured in terms of a few percent of sales, as is typical, this implies private-sector innovative efforts on energy measured in tens of billions of dollars per year. This is consistent with a recent IEA (2008a) estimate that places current global private-sector spending on energy technologies at $\$ 40-\$ 60$ billion annually, far exceeding public-sector spending of about $\$ 10$ billion annually.

This is illustrated in Table 2, which shows 2006 R\&D expenditures (including as a percent of sales) for the 1,250 companies that globally have the highest levels of R\&D investment (U.K. Department for Innovation, Universities and Skills 2007). The list includes producers of transportation technologies—such as Ford, DaimlerChrysler, Toyota, Boeing, and Rolls-Royce - which have individual company R\&D budgets measured in billions of dollars per year and which together contribute to a global R\&D budget for the automotive sector of $\$ 80$ billion annually. Electronic and electrical equipment companies spent over \$35 billion in R\&D in 2006, including companies like Siemens and Samsung, and general industrial companies, like 
Mitsubishi Heavy Industries and General Electric, which have annual R\&D budgets of over $\$ 11$ billion globally.

Chemical and agro-biotech companies, such as Bayer, BASF, DuPont, and Dow each have R\&D budgets above $\$ 1$ billion per year; these companies will be active in finding substitutes for GHGs and in engineering low-GHG biofuel alternatives. While elements of the energy sector focused on fossil-fuel extraction have relatively low R\&D intensities, they still have substantial R\&D budgets in aggregate. Furthermore, firms in the oil services sector that are likely to play an important role in developing geologic carbon storage, such as Schlumberger, spend hundreds of millions of dollars annually on R\&D and have higher R\&D intensities than the large oil companies.

In addition, many smaller firms and start-up companies have benefited from a recent surge in venture capital investment in clean energy technology. For example, early-stage venture capital investments directed to clean energy in the United States totaled about \$350 million in 2007, approximately double the figure for the prior year and starting from a negligible level just 10 years ago (Newell 2008; also see UNEP and New Energy Finance 2007). While relatively small, such companies can be an important source of productive innovative effort (Kortum and Lerner 2000).

Two main messages emerge from this discussion. First, substantial R\&D capacity exists in the principal sectors and companies relevant to GHG innovation. Evidence indicates that this private-sector innovative capacity will be directed to developing and commercializing low-GHG technologies — if increased demand is spurred by a price on GHG emissions. The second message is that the private-sector level of $R \& D$ spending on relevant products and processes is so substantial that failure to align private-sector profit incentives with societal GHG goals means that any public R\&D spending will likely push against an insurmountable tide. Pervasive incentives for GHG mitigation throughout the major economies will be necessary to reorient investment and innovation in a more climate-friendly direction. Nonetheless, such reorientation 
is not free and can be particularly costly if it comes at the expense of other R\&D. Increased demand for specialized $R \& D$ without a complementary increase in the supply of relevant $R \& D$ professionals runs the risk of displacing or crowding out other valuable research activities, or of increasing salaries rather than effort. Education and international scholarly exchange is therefore an important element of a balanced innovation strategy.

For a GHG policy to provide an effective inducement to innovation, however, it is critical that the private sector views the policy as credible over the long term. Given the sometimes substantial time lags between initial discovery and profitable market penetration, companies must be confident that there will indeed be sufficient demand once their innovations reach the market. Such confidence would be increased by domestic policies and international agreements that put in place GHG emission targets whose stringency is spelled out for many decades in advance, and that provide stable financial incentives across a wide array of technological solutions.

\section{Technology transfer through international trade and development assistance}

Domestic actions for emissions mitigation will be a critical feature of any internationally coordinated response to climate change that induces the necessary long-term innovation. Nonetheless, transferring the resulting technological knowledge and equipment internationallyand ensuring that technologies develop that are appropriate to different countries—will require additional actions at an international level. While technology transfer strategies must address typical impediments to technology adoption, such as information availability and technological maturity, they also must address financing barriers specific to developing countries. The degree of protection afforded to intellectual property rights and other conditions related to the rule of law, regulatory transparency, and market openness are also critical and can present impediments that bear on technology transfer. Intellectual property issues are discussed in the next section on upstream innovation strategies. 
The two principle mechanisms for promoting technology transfer between countries are international trade and international development assistance. In both cases, the rules and resources that underpin these mechanisms could be enhanced to enable a more effective response to global climate change. International trade and foreign direct investment are the main means by which new know-how and equipment are transferred among countries (World Bank 2008c), with private-sector investments constituting 86 percent of global investment and financial flows (UNFCCC 2007a). To enhance investment and financial flows to address climate change, it is therefore crucial to focus on private-sector investments. In addition to domestic actions that foster a positive environment for technology transfer investments through regulatory flexibility, transparency, and stability, specific international actions could be taken to reduce barriers to trade in environmental goods and services. A recent study on trade and climate change found that varied levels of tariffs and non-tariff barriers are a very significant impediment to the transfer of energy technologies to developing countries (World Bank 2008d). It estimated that eliminating these barriers could increase trade in four basic clean-energy technologies (wind, solar, clean coal, and efficient lighting) with high-GHG-emitting developing countries by 14 percent (World Bank 2008d). Note that the persistence of trade barriers—-despite the desire expressed by many developing countries for greater technology transfer-highlights the political challenge associated with development strategies that may have as their objective the acquisition of knowledge, but not products.

The World Trade Organization (WTO), with 153 members including all the largest GHG emitters (except Russia, which is in the process of accession), is the principle international forum for negotiating trade agreements. The ongoing Doha Round of trade negotiations explicitly covers trade in environmental goods and services, and in 2007 the United States and the European Union put forward specific proposals covering over $\$ 600$ billion of annual trade in environmental goods. They also proposed to prioritize negotiations on climate-friendly and energy-efficient technologies. 
A trade agreement specific to climate-friendly technologies could be constructed as a subcategory within a larger negotiated package on environmental goods or in a separate agreement, and could be structured to come into force when members representing a minimum percentage of trade in climate-friendly products joined (this is similar to the approach taken with the Information Technology Agreement) (World Bank 2007). Or a trade pact for climate-related technologies could be formulated as a plurilateral agreement-like the Agreement on Government Procurement-and could come into effect immediately and even independent of the conclusions of the Doha Round negotiations. Progress may also be possible within the WTO Working Group on Trade and Transfer of Technology (WGTTT), which was established as part of the Doha process to examine and make recommendations on WTO steps to increase flows of technology to developing countries (the WGTTT has so far produced no recommendations). Ongoing development and harmonization of technical standards relevant to climate mitigation technologies could also help facilitate trade and technology transfer; in fact, international professional associations have shown increased interest in examining the role for standards related to climate change and GHG management. ${ }^{3}$ Just as standards development can help reduce impediments to technology transfer and accelerate the development and adoption of new innovations, disparate, uncoordinated standards can impede such progress.

The largest source of public-sector support for cross-border finance is trade finance in its various forms. Export Credit Agencies (ECAs), such as the US Export-Import Bank and US Overseas Private Investment Corporation are often used by governments to support exports from domestic producers, usually through insurance, guarantees, favorable loan terms, or direct

\footnotetext{
${ }^{3}$ For example, the International Organization for Standardization has also begun cooperating with the IEA in identifying gaps and opportunities for standards to facilitate technology development and transfer (IEA 2007e) and the Institute of Electrical and Electronics Engineers Standards Association has launched a climate change study group. It could also be productive to coordinate these efforts with standards-related discussions within the WTO Committee on Trade and the Environment and WTO Committee on Technical Barriers to Trade.
} 
finance for export and overseas investment. As ECAs often provide support for energy-related technologies and can leverage significant private-sector funds, it is important that their investments are consistent with climate policy goals. The OECD has been the primary venue for discussing and coordinating international standards on the incorporation of environmental requirements for ECA support. In 2007, OECD countries agreed to stronger environmental rules for ECAs, including project environmental review and benchmarking to international (e.g., World Bank) standards (OECD 2007). Achieving these goals in the context of climate change mitigation will require implementation and ongoing review of these standards, development of specific guidelines related to climate impacts, and the extension of these rules to the ECAs of non-OECD countries such as China, Brazil, and India.

Lastly, although Official Development Assistance (ODA) funds are currently less than 1 percent of investment globally, ODA represents a larger share of investments (6 percent) in the least developed countries (UNFCCC 2007a). Therefore, bilateral and multilateral development assistance has an important role to play in climate change mitigation, especially if such assistance can be used to leverage private technology investments in a more climate-friendly direction. As the official financial mechanism of the UNFCCC, the Global Environment Facility (GEF) has been the main source of climate-specific ODA funding to date. Cumulative GEF investments since 1991 have totaled about $\$ 3.3$ billion for action on climate change in developing countries, with an additional \$14.4 billion leveraged through co-financing from bilateral ODA, recipient countries, and the private sector. More recently, the World Bank joined with regional development banks to approve a pair of climate investment funds in support of the Bali Action Plan: the Clean Technology Fund and the Strategic Climate Fund. These funds, for which the World Bank is seeking at least \$5 billion in support over the next three years (World Bank 2008a, 2008b), will provide resources for demonstration, deployment, and transfer of lowcarbon technologies. They will also serve as a vehicle for testing innovative approaches to climate change, including adaptation. 


\section{Complementary upstream technology innovation strategies}

The two most important international strategies for supporting the upstream supply and transfer of new climate technology innovations are (1) promoting increased and more effectively coordinated public funding of $\mathrm{R} \& \mathrm{D}$, and (2) resolving any impediments to knowledge transfer through intellectual property. To implement these strategies, the UNFCCC should consider establishing an Expert Group on Technology Development to focus on activities related to technology innovation. This group would complement the existing Expert Group on Technology Transfer, which is focused primarily on technology deployment and related financial mechanisms. Together, these expert groups would serve as the UNFCCC focal point for interactions with the IEA, WTO, and other international institutions. In that capacity they could provide advice to, and develop recommendations for, the Subsidiary Body for Scientific and Technological Advice concerning specific issues related to the development of innovative technologies and the transfer of related knowledge for climate mitigation.

International coordination and augmentation of climate mitigation $R \& D$

While private-sector effort dominates overall R\&D spending and performanceparticularly for product and process development—public funding of research is a significant and essential component of the overall innovation system for climate mitigation, in part because of the role it plays in building capacity by training future researchers. IEA member countries, which together account for about 85 percent of overall global R\&D expenditures, spent an estimated $\$ 11$ billion on publicly funded energy R\&D in 2006 (IEA 2007a)—or about 4 percent of overall public R\&D spending by these countries in the same year (Figure 3).

In real terms, this is about the same level of expenditure as in 1974, but it is a substantial reduction since 1980, when public spending by IEA countries on energy R\&D peaked at about $\$ 19$ billion in real terms (or over 11 percent of overall public R\&D funding). Public energy R\&D budgets declined in every country except Japan over this period (that is, 1980-2006), and remain especially low in many European countries. Low fossil-fuel prices, deregulation of the natural 
gas and electric utilities industries in several countries, and a lack of political interest led to tandem declines in both private and public energy R\&D spending. In recent years, however, the new energy technology challenges posed by global climate change, combined with heightened concerns over energy security, have significantly increased the prospective value of increased public funding for energy-related research. In response, funding levels have stabilized and the trend has been changing, with the most recent budgets in some countries, such as the United States, measurably increasing public funds directed to energy R\&D. Priorities for public energy R\&D budgets have also shifted significantly, with most energy research being reoriented in a direction that supports GHG mitigation, either by supporting nuclear, renewable, and energy efficiency R\&D, or by supporting fossil energy R\&D to facilitate carbon capture and storage.

Given the current level of energy R\&D spending relative to the magnitude of the climate technology challenge and the magnitude of the potential payoff from innovative technology (likely measured in the hundreds of billions of dollars), it seems clear that a significant expansion of public spending on energy R\&D by developed nations is warranted-in tandem with expanded private R\&D in response to market demand. For example, recent IEA (2008a) and UNFCCC (2007a) assessments of financial requirements to respond to climate mitigation needs, conclude that it will be necessary to at least double clean-energy R\&D to stabilize or significantly reduce GHG emissions within the next several decades. ${ }^{4}$ Many innovations that address climate concerns also address energy security and local pollution concerns, in addition to

\footnotetext{
${ }^{4}$ Suggestions that what we really need is a "Manhattan Project” or "Apollo Project" approach to climate mitigation R\&D are misguided, however, for several reasons. For both of those efforts the government was the sole customer for a single, well-defined project. This is in contrast to energy markets that are driven by millions of diverse users of a multitude of technologies. Cost was also not a key concern for the Manhattan or Apollo projects, whereas with climate technology innovation cost-competitiveness is the central issue. Those efforts also gave rise to a relatively short-lived burst of spending to solve a discrete problem, whereas what is likely to be required for climate technology innovation is steady incremental improvement over many decades. See Yang and Oppenheimer (2007) for a related discussion.
} 
yielding broader economic benefits. Studies find that accounting for these non-climate benefits further increases the value of energy R\&D, often significantly (Newell 2008). It will therefore be valuable to target funding at areas that hold promise for addressing multiple energy challenges at the same time. Innovations that increase energy efficiency have this potential, as do supply-side innovations for renewable energy, advanced nuclear power, and carbon capture and storage that increase fuel diversity while reducing multiple pollutants.

While the case for expanding domestic R\&D on climate mitigation technologies is compelling, and the potential benefit of international cooperation seems clear, the question remains as to what specifically would be valuable and feasible to coordinate and agree to at an international level. The possibilities include agreements for knowledge sharing and coordination of $R \& D$, joint collaboration and funding of $R \& D$, and commitments on increased domestic $R \& D$ funding. Given the centrality of the IEA to international energy-technology cooperation, the IEA should also consider means to more regularly and deeply involve non-OECD countries such as Brazil, China, India, South Africa, and Russia in IEA programs, including accelerating the accession of such countries to the IEA (either in conjunction with or in advance of accession to the OECD).

\section{International agreement on $R \& D$ knowledge sharing, coordination, and joint}

collaboration and funding. Activities undertaken under knowledge-sharing and coordination agreements can include meeting, planning, exchanging information, coordinating and harmonizing research agendas and measurement standards, and engaging in some degree of integrated, cooperative R\&D (de Coninck, et al. 2008, IEA 2008a). In addition, other agreements have emerged in recent years, including the Carbon Sequestration Leadership Forum, the Asia Pacific Partnership on Clean Development and Climate, and the International Partnership for a Hydrogen Economy. Energy science and technology agreements that feature a higher degree of joint, collaborative R\&D are less common, and appear to be most successful in research that is more fundamental and that has not yet attracted a critical mass of commercial interest. Examples 
include the ITER fusion reactor and European Organization for Nuclear Research (CERN) (de Conninck, et al. 2008). In addition to expanding the international exchange of scientific and technical information, joint R\&D can more directly increase cost-effectiveness through cost sharing and reduced duplication of effort.

Most existing international agreements relevant to climate mitigation technology have been developed as so-called Technology Implementing Agreements under the auspices of the IEA, organized under its Committee on Energy Research and Technology (Figure 4). IEA Implementing Agreements use two primary mechanisms: task sharing and cost sharing. In task sharing, a joint program is pursued within participating countries, but each country funds and implements its own contribution to the project. In cost sharing, participating countries pool funding for a single contractor to perform a research task. There are forty-one existing IEA Implementing Agreements, all of which incorporate task sharing and about half of which have cost sharing. They cover the fields of renewable energy and hydrogen (10), end-use energy efficiency (13), fossil-fuel technologies (6), nuclear fusion energy (9), and cross-cutting activities (3) (IEA 2007f). Membership in these agreements is not restricted to governments or to IEA or OECD countries — indeed, a number of organizations from non-OECD countries have participated. Activities under these agreements are funded and conducted primarily through domestic R\&D programs and budgets, and pooled funds often go to bundling research results and providing a platform for information exchange and learning (i.e., desk studies rather than primary research).

Invigorated and expanded international agreements on the coordination of public R\&D in the area of climate technology could be very valuable, particularly as countries increase R\&D efforts and seek maximal impact in addressing this global problem. The IEA is the bestpositioned international institution to support agreement(s) related to energy technology, although it may be more appropriate to engage other international institutions for non-energy technologies. One concern with the existing IEA implementing agreements, however, is that they 
each have their own secretariats, operate independently, and have not undergone regular systematic review. While this approach eases the need for more central administration, it may also suffer from overlap across agreements, and a lack of overall coordination and strategic vision. Another concern is that countries that have formal IEA membership-which is currently limited to OECD countries — may have greater control over decision processes. One approach for addressing that concern is to explicitly include the new UNFCCC Expert Group on Technology Development recommended above within the decision-making processes of agreements that may be supported by the IEA. Another approach is to formally broaden IEA membership to include key emerging economies, in concert with, or aside from, OECD membership.

G8 countries, other major R\&D-performing countries, and likely major developingcountry technology users should therefore consider agreeing to an overall framework for knowledge sharing and coordination of public R\&D efforts in the area of climate mitigation. This framework could include a process whereby parties regularly submit climate-technology development plans that cover R\&D funding levels, current and future program plans, pertinent R\&D policies, and other relevant information. One way to think of these plan submissions is as supply-side counterparts to the Technology Needs Assessments that have been prepared by many developing countries under the UNFCCC (2007). In addition to country-level plan submissions, the overall framework could provide for an evaluation of existing climate technology agreements — with an eye toward identifying best practices and expanding, integrating, or suspending particular agreements - and draw from other related national-level and international efforts by the European Union (European Commission 2007b), Japan (METI 2008), and the United States (USDOE 2006) as well as from IEA work in support of the G8 and other processes (IEA 2008b).

At a minimum, participants would work together to monitor progress, share information on individual national efforts in an integrated manner, and identify where overlaps and gaps exist across countries. This framework could also provide for the development of roadmaps to assess 
the current status of particular technologies, systems, and relevant areas of underlying science, including the identification of appropriate milestones and necessary public R\&D funding levels. It would also provide a more systematic means for improving the cost-effectiveness of public R\&D by identifying particular areas where it makes sense for individual countries to focus on sub-parts of an integrated overall package and areas where joint funding is sensible. For example, such a framework could be used to organize and fund joint projects to demonstrate carbon capture and storage technology. An agreement could also set out general guidelines outlining expectations with regard to the scope and magnitude of task and cost sharing across countries in the context of collaborative R\&D projects. Finally, this framework could highlight the importance of human talent to both knowledge development and transfer, by helping to identify high-priority areas for scholarly exchange_-including from developing to developed countries.

In addition to the traditional approach of using research contracts as the means to award joint R\&D funding, another option is to offer internationally coordinated prizes for achieving specific advances in climate-related science and technology. The idea is to offer financial or other rewards for achieving specific innovation objectives that have been specified in advance (in contrast to ex-post awards like the Nobel Prize) (Newell and Wilson 2005, National Research Council 2007). ${ }^{5}$ Prize-like approaches have also gained traction within the private sector: Firms like Innocentive match “seekers” (organizations that wish to address challenging problems) with “solvers” (innovators with solutions) by offering them cash awards. Among other things,

\footnotetext{
${ }^{5}$ Recently proposed prizes relevant to energy and climate policy include "Prizes for Achievement in Grand Challenges of Science and Technology" authorized in the US Energy Policy Act of 2005, the H-Prize (for hydrogen) and Bright Tomorrow lighting prizes authorized in the US Energy Independence and Security Act of 2007, the privately-funded Progressive Automotive X-Prize, and the Earth Challenge Prize announced by British financier Richard Branson. Only the last two private prizes have been funded.
} 
Innocentive has a philanthropic subprogram that is devoted to clean technology and renewable energy and that offers prizes supported by a private foundation.

Although inducement prizes are not suited to all research and innovation objectives, they have the potential to play a larger role alongside research contracts and grants. In contrast to these other instruments, prizes target and reward innovation outputs rather than inputs: The prize is paid only if the objective is attained. This can help encourage maximal research effort per dollar of research funding. Prizes or awards can also help focus efforts on specific high-priority objectives, without specifying how the goal is to be accomplished. Because prize competitors select themselves based on their own knowledge of their likelihood of success-rather than being selected in advance by a research manager_-prizes can also attract a more diverse and potentially effective range of innovators from the private sector, universities, and other research institutions.

In an international context, a prize approach could have the advantage that the winner of R\&D funding does not have to be chosen in advance, thus avoiding a selection process that can become politically charged when researchers and research institutions reside in particular countries. Just as the Olympics engender a spirit of both international cooperation as well as competitive record-breaking, technology prize competitions could play an important role in international climate R\&D. Prizes could be particularly useful for advancing innovation relevant to the mitigation and adaptation technology needs of developing countries, given the relatively low levels of market-driven inducement for innovation that may be present in those countries. For similar reasons, the use of innovation prizes has been advocated for medical advances particularly relevant to developing countries (e.g., anti-malaria drugs) (Love and Hubbard 2007).

The detailed process of selecting appropriate prize topics and crafting prize-specific rules (e.g., the type of contest, size of award, criteria for winning, method of choosing the winner) requires extensive consultation with experts and potential participants (National Research Council 2007). Identifying particular technical and scientific challenges in GHG mitigation that 
could be fruitfully addressed through an inducement prize approach could be identified as part of the above systematic assessment. Then the best institutional arrangements for administering the prize would need to be determined. Consideration would need to be given to the treatment of intellectual property arising from associated innovations (as with any joint R\&D project), and to the development of terms for related licensing. ${ }^{6}$ An international climate technology prize fund would also need to be established, with contributions potentially coming from national governments, as well as foundations, individuals, and corporations. While contributions for such a fund could be sought on an as-needed basis for specific projects, it would probably be advantageous to have larger-scale general funds that could then be prioritized to specific prize topics. ${ }^{7}$

\section{International agreement on domestic climate technology $R \& D$ funding. An}

international agreement could also be fashioned to increase domestic funding of climate technology R\&D, analogous to internationally agreed emission targets for each country. An international agreement on the necessary level of R\&D funding and reasonable burden sharing of R\&D efforts across parties could be valuable. Such an agreement could, for example, target a level of climate technology $R \& D$ as a percentage of GDP, or as a percentage increase from recent levels, with those levels set to reflect a significant expansion of $R \& D$. The general idea is not without precedent: In 2002, the European Union set the goal of increasing its relatively low

\footnotetext{
${ }^{6}$ Note that while, in theory, prizes are often conceived as a substitute for patents, in practice, inducement prizes often do not preclude patenting.

${ }^{7}$ An important consideration for any joint fund of this type is the incentive for entities to contribute, rather than free ride on the contributions of others. Barrett (2003) suggests an approach whereby individual country contributions to an R\&D fund would depend on the other countries participating. The incentives for participation and compliance are increased by a mutually enforcing participation clause, while a cap on the total fund ensures that countries know their maximum costs. If one country accedes, then all the other parties would increase their funding by a specified amount; alternatively, if that country withdraws, the others lower their funding. While not a panacea, this approach merits consideration.
} 


\section{Richard Newell}

level of overall R\&D spending — currently at 1.8 percent of GDP (OECD 2008)— to 3 percent of GDP by 2010. The goal is EU-wide rather than country-specific and applies jointly to both public and private R\&D funding. However, there is little evidence of measurable progress toward the goal thus far, although ongoing discussions among government representatives and major R\&D-performing companies have illuminated many of the key impediments. A more detailed example-albeit in the medical rather than climate arena-is the 2005 proposal to the World Health Organization for a Treaty on Medical Research and Development. ${ }^{8}$ The core country obligations in the proposal are for minimum levels of support for qualified medical R\&D (both general and “priority” areas), measured as a share of GDP, according to a schedule that varies by national income. Among other things, the proposal also identifies methods of qualified R\&D financing (e.g., direct public support, tax expenditures, philanthropic expenditures, and certain business R\&D).

Specifically with regard to energy, the IEA already collects annual data on public energy R\&D spending by IEA countries, a process that could be adjusted if necessary to serve a more formal purpose. To operationalize such a commitment, it would probably have to exclude private-sector climate-related $R \& D$ expenditures, which are difficult to distinguish from other R\&D. Such an agreement could incorporate a "pledge and review” structure, and the necessary reporting on funding levels could be integrated with the regular climate-technology development plans described above. Targets could be structured as a share of GDP, as a percentage increase from recent levels, or some other metric. The IEA could serve as the review body-either directly or as an assistant to a UNFCCC Expert Group on Technology Development. The process could also include a broader energy innovation policy review element: The IEA already conducts

\footnotetext{
${ }^{8}$ A copy of the proposal can be found at www.cptech.org/workingdrafts/rdndtreaty.html. See Love and Hubbard (2007) for a related background discussion.
} 
regular reviews of the energy policies, including energy-technology policies, of IEA member countries and other major energy consumers and producers (see, for example, IEA 2006).

\section{Knowledge transfer through intellectual property}

Protecting intellectual property through patents is one of the principal means by which innovators can capture value associated with developing new GHG-reducing technologies. By providing a mechanism for appropriating the value of innovation beyond the boundaries of a firm, patents and other forms of intellectual property protection (e.g., industrial designs, trademarks, copyrights) can stimulate innovative activity that might not otherwise take place, or at least not be pursued as intensely. In return, patents require that the invention be disclosed to the public, which allows future innovators to build on that knowledge and ensures that new knowledge is freely available after the patent expires (usually in twenty years). In a related manner, the ability to secure a patent can also increase technology transfer-whether to industry from a university or government laboratory, or from one country to another-by rewarding the innovator (or subsequent patent owner) for taking the necessary steps to move ideas to ultimate users. Otherwise innovators may keep their inventions secret, thereby stifling the application of those innovations as well as follow-on innovation.

On the other hand, patents assign a temporary monopoly right, which tends to lead to higher prices and which could impede the near-term diffusion of products or processes that embody the patent. In addition, obstacles to follow-on innovation could arise in the process of securing licenses for foundational patents, or if there is a "thicket” of overlapping patents that must be cleared. Firms may simply be unwilling to grant licenses out of concern that intellectual property rights will not be respected in certain countries. In the context of climate change, therefore, developing-country parties have often held that intellectual property rights are a barrier to technology transfer and that options such as compulsory licensing and greater access to technologies in the public domain should be considered. Others counter that intellectual property protection encourages technology development and transfer, that intellectual property costs are a 
small portion of overall technology costs, and that many existing climate-friendly technologies are no longer protected by patents. Research to examine these competing claims in the specific context of climate-friendly technologies has so far been limited (Reichman et al. 2008). In an analysis of existing solar, wind, and biofuel technologies, for example, Barton (2007) found that intellectual property has elicited innovation without significantly impeding technology transfer, although problems could arise if new, very broad patents were granted that impede the development of future, more efficient technologies. Views on these issues are diverse, however, and probably warrant further discussion and possible action at an international level, a discussion that has only recently begun among the relevant international institutions. ${ }^{9}$

The two key international institutions for developing and implementing intellectual property policies are the World Intellectual Property Organization (WIPO), a specialized agency of the United Nations that administers numerous intellectual property treaties, and the WTO, through the Agreement on Trade-Related Aspects of Intellectual Property Rights (TRIPS). To improve dialogue, better integrate climate-related and other ongoing discussions where they interface with intellectual property, environment, and sustainable development issues, and identify productive solutions, the UNFCCC, WIPO, and WTO should consider seeking observer status with the other institutions. Within WIPO, the UNFCCC, through its Expert Groups on Technology, would actively engage the recently launched Committee on Development and Intellectual Property (WIPO 2008a, 2008b). As existing observers to the WTO Committee on Trade and Environment, the UNFCCC and WIPO should consider engaging with the WTO

\footnotetext{
9 The current state of this discussion is illustrated by presentations at the workshop "Life Sciences Symposium on Patent Landscaping and Transfer of Technology under Multilateral Environmental Agreements,” sponsored by the World Intellectual Property Organization, Geneva, August 2008

(http://www.wipo.int/meetings/en/2008/lifesciences/ip_lss2_ge/) and the “European Patent Forum 2008: Inventing a Cleaner Future”, Ljubljana, Slovenia, May 2008 (http://www.epo.org/about-us/events/archive/2008/epf2008/forum1/details2_fr.html).
} 
TRIPS Council and, if useful, the UNFCCC should seek observer status specifically with the TRIPS Council. Coordination with the WTO WGTTT may also be desirable.

These bodies would work jointly to identify technology development and transfer opportunities and impediments associated with the intellectual property system, advance recommendations for harnessing opportunities and reducing impediments, identify best practices, and expand technical assistance and capacity-building activities to facilitate the development and transfer of innovations for climate-change mitigation. Parties to the UNFCCC and WIPO should consider establishing a fund within the WIPO for these purposes; another possibility would be to use the new Strategic Technology Fund at the World Bank (although the immediate focus of that fund appears to be adaptation). Among other purposes, such a fund could potentially be used to purchase intellectual property rights (which could be placed in the public domain) and cover licensing fees, royalties, and other costs related to intellectual property (e.g., application, examination, registration fees), if and where this would be an effective means of increasing technology transfer. It is also worthwhile to consider whether conditioning the receipt of such support on the implementation of best practices in a particular country would increase the leverage of this approach-in terms of both promoting technology transfer and enhancing the willingness of developed countries to contribute to such a fund.

\section{Conclusion}

The range of opportunities for improving and expanding international climate technology development and transfer extends well beyond the usual boundaries of environmental decisionmakers to the broader context of international agreements and institutions for energy, trade, development, and intellectual property. Recognizing that any successful effort to accelerate and then sustain a higher rate of climate-technology development and transfer must harness a diverse set of markets and institutions, the following specific issues and actions should be considered within the post-2012 dialogue: 


\section{Richard Newell}

- Given the centrality of private-sector trade, investment, and innovative effort in technology, widespread global demand for low-GHG technologies will be essential to move the energy system in the desired direction. Long-term national commitments and policies for emission mitigation are crucial to providing the necessary privatesector incentives for technology development and transfer.

- For developing countries, financial assistance for technology transfer and capacity building is also necessary. At the same time, GHG-related guidelines for financing by ECAs and multilateral development banks can help ensure that investments in trade and development assistance are consistent with climate mitigation goals.

- In addition to increased incentives, barriers to the transfer of climate-friendly technologies could be reduced through a WTO agreement to reduce tariff and nontariff barriers to trade in environmental goods and services. Efforts to develop and harmonize technical standards — by international standards organizations in consultation with the IEA and WTO_could help reduce impediments to technology transfer and accelerate the development and adoption of climate-friendly innovations.

- A framework for coordinating and augmenting climate-technology R\&D could be organized through a UNFCCC Expert Group on Technology Development, supported by the IEA. Broadening IEA participation to large non-OECD energy consumers and producers could also facilitate such coordination. An agreement could include a process for reviewing country submissions on technology development, along with a process for identifying redundancies, gaps, and opportunities for closer collaboration. A fund for cost-shared R\&D tasks and international prizes could be established to provide financing for innovative efforts to advance science and technology objectives that are best accomplished in a joint fashion. The agreement could also include explicit targets for increased domestic R\&D spending on GHG mitigation. 
- A UNFCCC Expert Group on Technology Development, WIPO, and the WTO could work jointly to develop recommendations for addressing technology development and transfer opportunities and impediments associated with the intellectual property system. A fund could be established in WIPO or another appropriate body for related technical assistance, capacity building, and possibly to purchase intellectual property or cover its costs.

Climate-technology policy must complement rather than substitute for policies that provide a direct financial incentive for emission mitigation. R\&D without market demand for the results would ultimately have limited impact, while stimulating market demand for emissions mitigation without supportive technology policies misses longer-term opportunities for significantly lowering mitigation costs and expanding opportunities for greater GHG mitigation. Impediments to the international transfer of know-how and equipment also should be reduced. The scale of the technology problem we confront in effectively managing climate risks while simultaneously addressing other major energy issues is such that it requires a portfolio of strategies for reducing barriers and increasing incentives across multiple international institutions and agreements. This is also the only way to maximize the impact of the scarce resources that are available for addressing climate change and other critical societal challenges. 
Figures and Tables

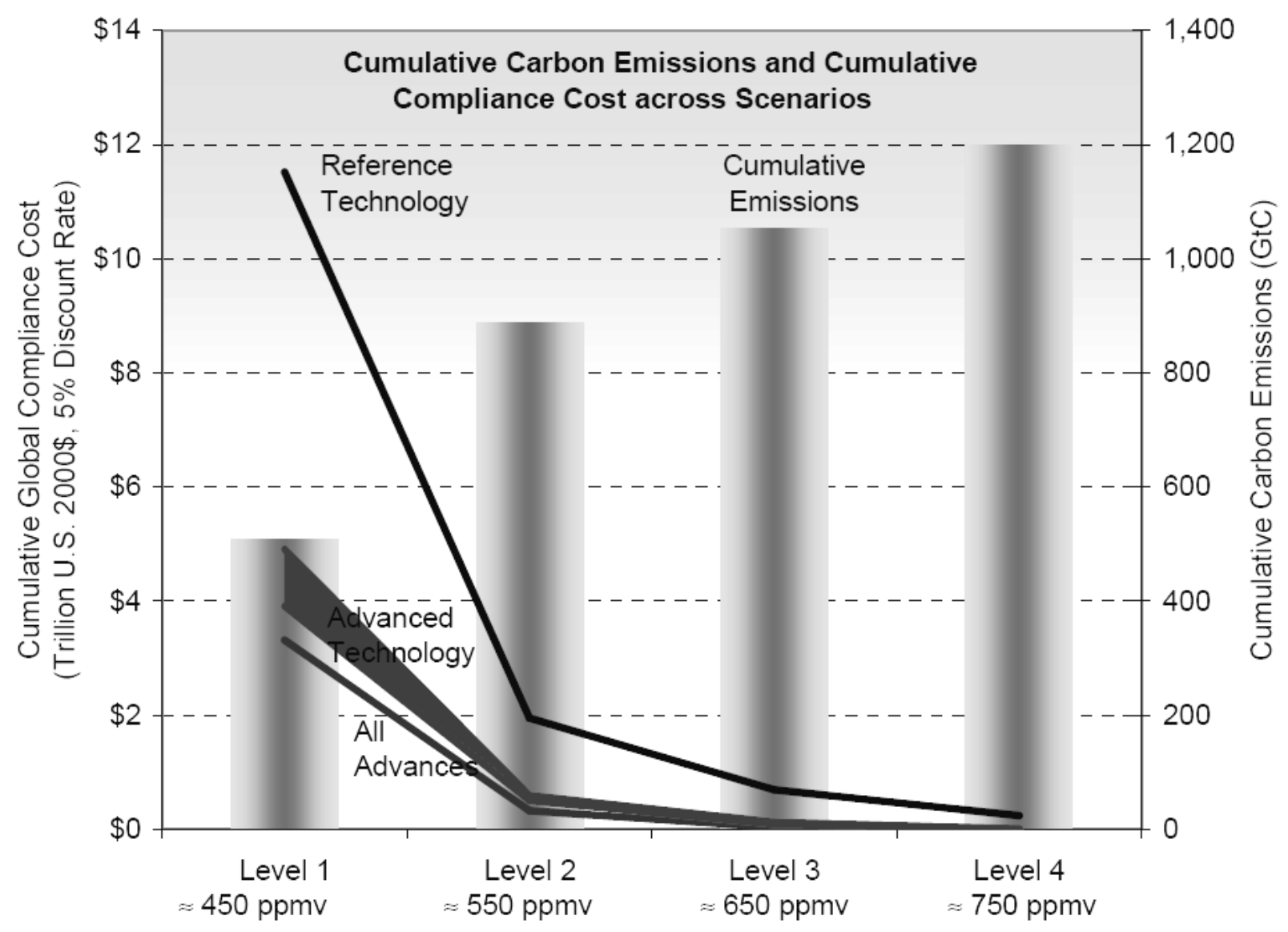

Source: Clarke et al. (2006, p. 6.5).

Figure 1. Cumulative global mitigation costs under alternative technology scenarios 


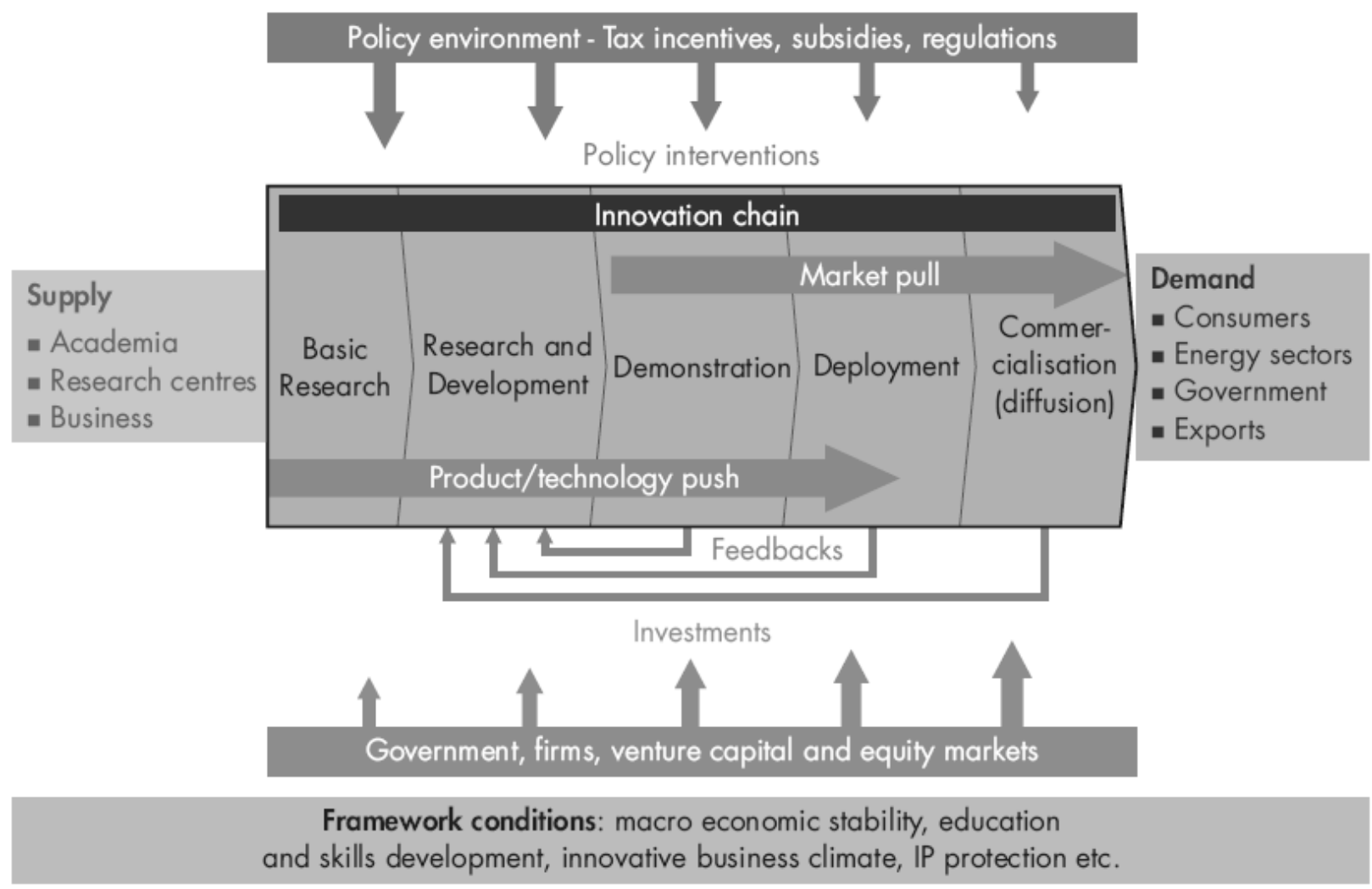

Source: IEA (2008a).

Figure 2. Schematic of the innovation system 


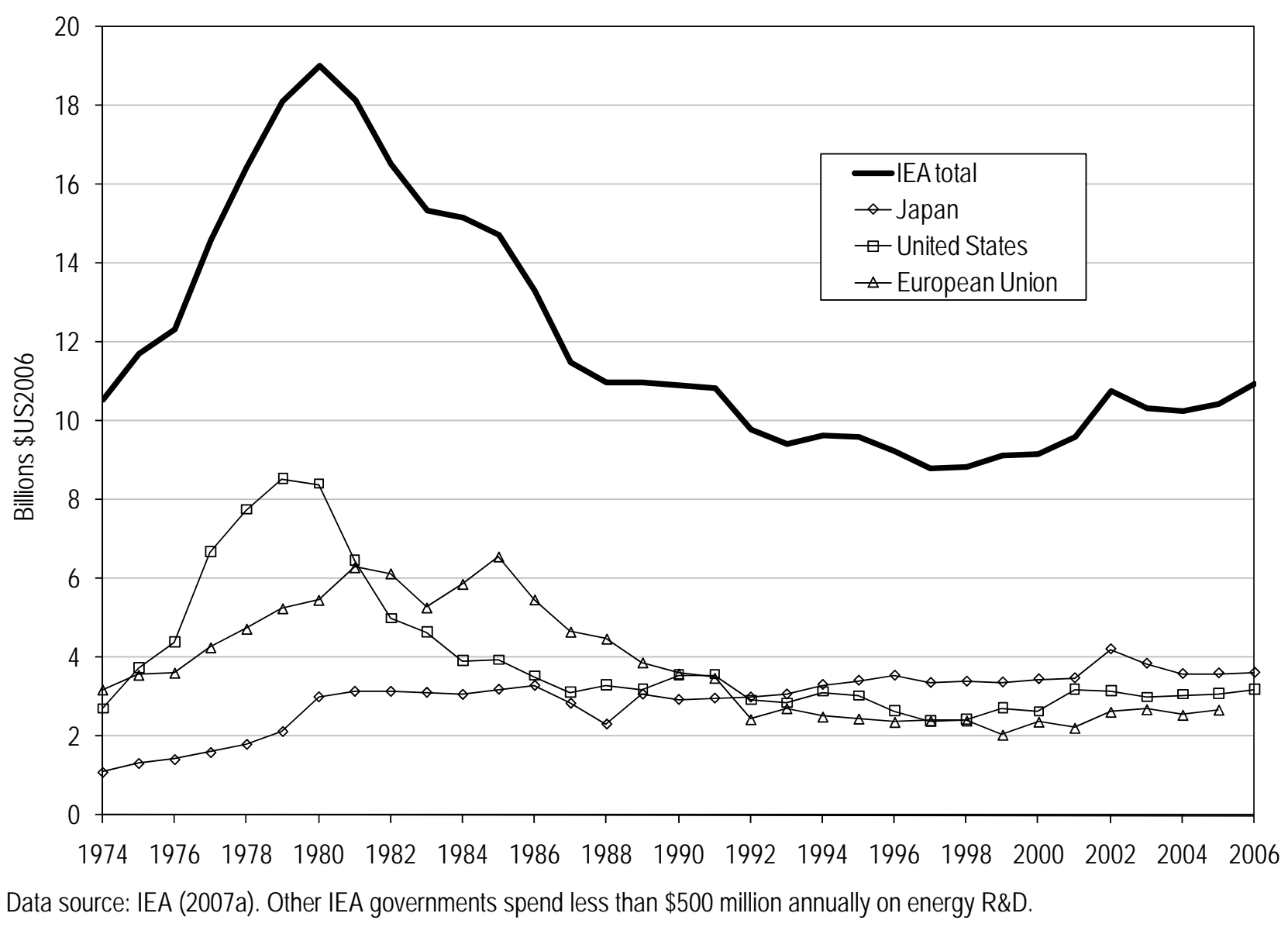

Figure 3. Public energy R\&D spending in IEA countries (1974-2006) 
Richard Newell

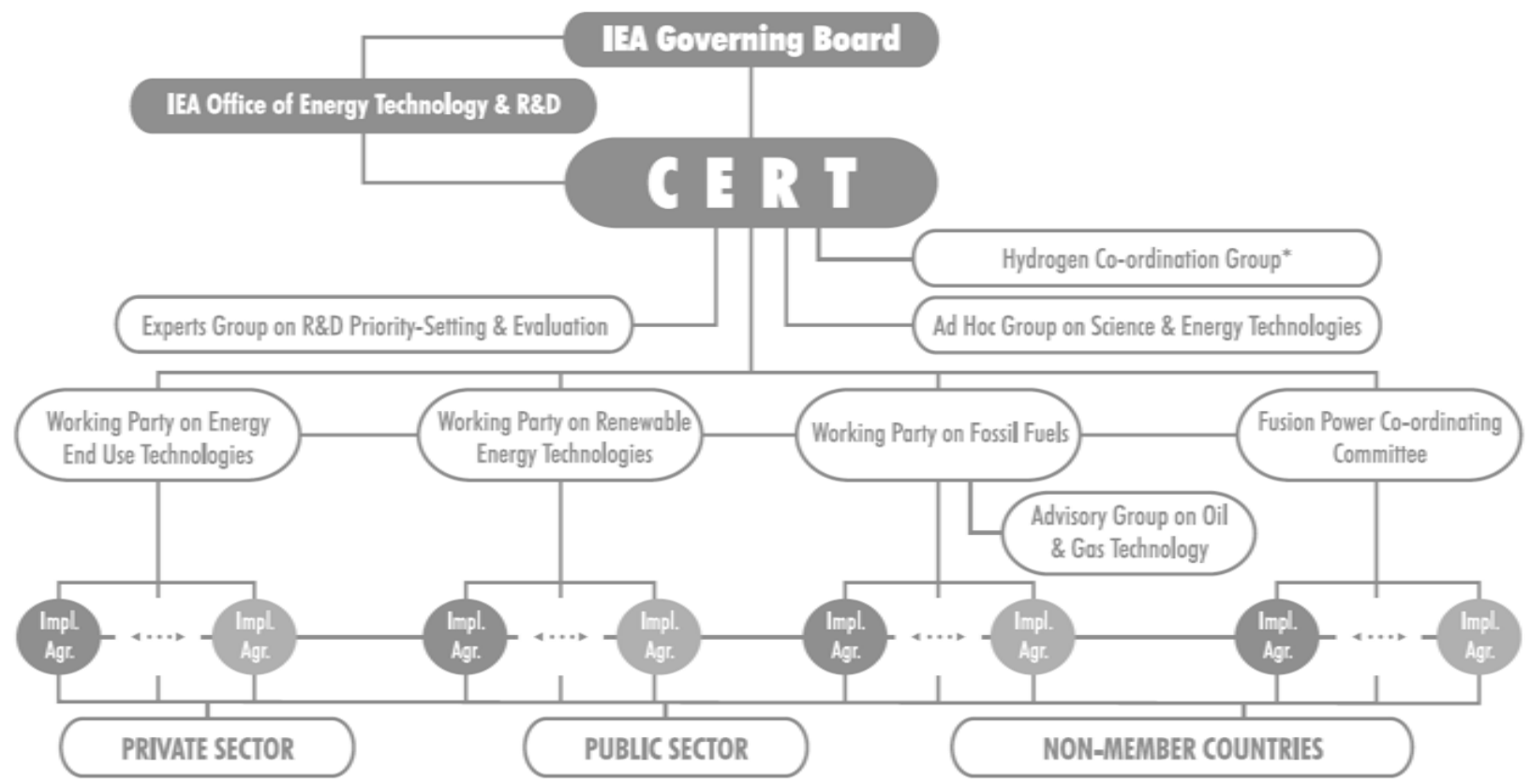

Source: IEA (2007c).

Figure 4. IEA Committee on Energy Research and Technology (CERT) 
Richard Newell

Table 1. International R\&D Expenditures in 2006 (units as indicated)

\begin{tabular}{|c|c|c|c|c|c|c|c|c|}
\hline \multirow[b]{2}{*}{ Country } & \multicolumn{2}{|c|}{ All sources } & \multicolumn{2}{|c|}{ Percent financed by } & \multicolumn{3}{|c|}{ Percent performed by } & \multirow{2}{*}{$\begin{array}{l}\text { Researchers } \\
\text { (1000 FTEs) }\end{array}$} \\
\hline & $\begin{array}{r}\text { (US\$ } \\
\text { billions) } \\
\end{array}$ & $\begin{array}{r}\text { Percent } \\
\text { world R\&D } \\
\end{array}$ & Industry & Government & Industry & Universities & Government & \\
\hline United States & 344 & 35.8 & 65 & 29 & 70 & 14 & 11 & 1,388 \\
\hline Japan & 139 & 14.4 & 77 & 16 & 77 & 13 & 8 & 710 \\
\hline Germany & 67 & 6.9 & 68 & 28 & 70 & 16 & 14 & 282 \\
\hline France & 41 & 4.3 & 52 & 38 & 63 & 18 & 17 & 204 \\
\hline United Kingdom & 36 & 3.7 & 45 & 32 & 62 & 26 & 10 & 184 \\
\hline Canada & 24 & 2.5 & 48 & 33 & 54 & 36 & 9 & 125 \\
\hline Russia & 20 & 2.1 & 29 & 29 & 67 & 6 & 27 & 464 \\
\hline Italy & 18 & 1.8 & 40 & 51 & 50 & 30 & 17 & 82 \\
\hline Other EU-27 & 82 & 8.5 & 51 & 37 & 60 & 25 & 14 & 199 \\
\hline G-8 total & 770 & 80.0 & 62 & 29 & 68 & 17 & 12 & 3,637 \\
\hline Korea & 36 & 3.7 & 75 & 23 & 77 & 10 & 12 & 200 \\
\hline Australia & 12 & 1.2 & 53 & 41 & 54 & 27 & 16 & 81 \\
\hline Mexico & 6 & 0.6 & 47 & 45 & 50 & 27 & 22 & 48 \\
\hline Turkey & 5 & 0.5 & 46 & 49 & 37 & 51 & 12 & 43 \\
\hline Switzerland & 7 & 0.7 & 70 & 23 & 74 & 23 & 1 & 25 \\
\hline Norway & 4 & 0.4 & 46 & 44 & 54 & 30 & 16 & 22 \\
\hline New Zealand & 1 & 0.1 & 41 & 43 & 42 & 33 & 26 & 17 \\
\hline OECD total & 818 & 85.0 & 64 & 30 & 69 & 17 & 11 & 3,979 \\
\hline OECD + Russia & 838 & 87.1 & 62 & 30 & 69 & 17 & 11 & 4,443 \\
\hline China & 87 & 9.0 & 69 & 25 & 71 & 9 & 20 & 1,223 \\
\hline Chinese Taipei & 17 & 1.8 & 67 & 31 & 68 & 12 & 20 & 95 \\
\hline Israel & 8 & 0.8 & 69 & 23 & 78 & 13 & 5 & - \\
\hline Singapore & 5 & 0.5 & 59 & 36 & 66 & 24 & 10 & 25 \\
\hline South Africa & 4 & 0.4 & 44 & 38 & 58 & 19 & 21 & 17 \\
\hline Argentina & 2 & 0.2 & 29 & 67 & 30 & 27 & 41 & 35 \\
\hline Romania & 1 & 0.1 & 30 & 64 & 49 & 18 & 32 & 21 \\
\hline World total* & 962 & 100 & 63 & 30 & 69 & 16 & 13 & 5,859 \\
\hline
\end{tabular}

Source: OECD (2008). Non-U.S. totals are based on purchasing power parity (PPP) exchange rates.

*Note: Non-OECD total covers only select non-OECD countries and thus the non-OECD and world totals may represent underestimates; however, almost all R\&D occurs in the included countries. 
Richard Newell

Table 2. R\&D Expenditures for Top R\&D-Spending Companies Worldwide (for 2006, units as indicated)

\begin{tabular}{lrr}
\hline \hline Sector (number of companies) & \multicolumn{2}{c}{ R\&D } \\
& US\$(millions) & Percent of sales \\
\hline \hline All sectors (1,250) & 478,129 & 3.5 \\
Aerospace \& defence (39) & 21,160 & 4.9 \\
Automobiles \& parts (78) & 80,284 & 4.1 \\
Chemicals (91) & 22,341 & 3.1 \\
Construction \& materials (23) & 2,374 & 0.9 \\
Electricity (16) & 2,918 & 0.9 \\
Electronic \& electrical equipment (102) & 35,150 & 4.5 \\
Forestry \& paper (8) & 573 & 0.5 \\
Gas, water \& multiutilities (7) & 738 & 0.3 \\
General industrials (36) & 11,583 & 2.1 \\
Household goods (24) & 5,011 & 2.3 \\
Industrial engineering (70) & 11,737 & 2.7 \\
Industrial metals (23) & 3,201 & 0.8 \\
Industrial transportation (6) & 440 & 0.3 \\
Mining (3) & 604 & 0.7 \\
Oil \& gas producers (18) & 6,465 & 0.3 \\
Oil equipment, services \& distribution (10) & 1,748 & 1.9 \\
Pharmaceuticals \& biotechnology (157) & 92,881 & 15.9 \\
Software \& computer services (113) & 34,359 & 10.1 \\
Technology hardware \& equipment (207) & 84,517 & 8.6 \\
\hline \hline Note: Table includes sectors that may be relevant to GHG innovation, as well as & \\
certain very large R\&D-performing sectors, from the R\&D Scorecards 1,250 companies \\
globally with the highest R\&D expenditures (U.K. Department for Innovation, \\
Universities and Skills 2007). These 1,250 companies account for about 80 percent of \\
global industry R\&D. & & \\
& &
\end{tabular}




\section{References}

Barrett, Scott. 2003. Environment and Statecraft. Oxford, UK: Oxford University Press.

Barton, John S. 2007. "Intellectual Property and Access to Clean Energy Technologies in Developing Countries: An Analysis of Solar Photovoltaic, Biofuel and Wind Technologies.” Issue Paper 2, Trade and Sustainable Energy Series, Stanford Law School, Stanford University, Palo Alto, CA.

Clarke, Leon E., James A. Edmonds, Henry D. Jacoby, Hugh M. Pitcher, John M. Reilly, and Richard G. Richels. 2007. "Scenarios of Greenhouse Gas Emissions and Atmospheric Concentrations.” Synthesis and Assessment Product 2.1a Report by the U.S. Climate Change Science Program and the Subcommittee on Global Change Research, Washington, DC.

Cohen, Linda R. and Roger G. Noll. 1991. The Technology Pork Barrel. Washington, DC: Brookings.

de Coninck, Helen, Carolyn Fischer, Richard G. Newell, and Takahiro Ueno. 2008. International technology-oriented agreements to address climate change. Energy Policy 36:335-356.

Edmonds, Jae, A., M.A. Wise, James J. Dooley, S.H. Kim, S.J. Smith, Paul J. Runci, L.E. Clarke, E.L. Malone, and G.M. Stokes. 2007. "Global Energy Technology Strategy: Addressing Climate Change.” Joint Global Change Research Institute, College Park, MD.

European Commission. 2007a. "Limiting Global Climate Change to 2 degrees Celsius: The Way Ahead for 2020 and Beyond." Communication from the Commission to the Council, the European Parliament, the European Economic and Social Committee, and the Committee of the Regions. European Commission, Brussels, Belgium.

European Commission. 2007b. “European Strategic Energy Technology Plan.” European Commission, Brussels, Belgium.

Fisher, B.S., N. Nakicenovic, K. Alfsen, J. Corfee Morlot, F. de la Chesnaye, J.-Ch. Hourcade, K. Jiang, M. Kainuma, E. La Rovere, A. Matysek, A. Rana, K. Riahi, R. Richels, S. Rose, D. van Vuuren, R. Warren. 2007. Issues related to mitigation in the long term context. In Climate Change 2007: Mitigation. Contribution of Working Group III to the Fourth Assessment Report of the Inter-governmental Panel on Climate Change [B. Metz, O.R. Davidson, P.R. Bosch, R. Dave, L.A. Meyer (eds)]. Cambridge University Press: Cambridge, United Kingdom and New York, NY, USA.

IPCC (Intergovernmental Panel on Climate Change). 2000. Methodological and Technological Issues in Technology Transfer: Summary for Policymakers. A Special Report of IPCC Working Group III of the Intergovernmental Panel on Climate Change. IPCC: Geneva, Switzerland.

IPCC. 2007. Climate Change 2007: Synthesis Report. Contribution of Working Groups I, II and III to the Fourth Assessment Report of the Intergovernmental Panel on Climate Change [Core Writing Team, Pachauri, R.K and Reisinger, A.(eds.)]. IPCC: Geneva, Switzerland. 
IEA (International Energy Agency). 2006. Energy Policies of IEA Countries: 2006 Review. Paris: OECD/IEA.

IEA. 2007a. Energy Technology RD\&D Budgets 2007. Paris: OECD/IEA.

IEA. 2007b. World Energy Outlook 2007. Paris: OECD/IEA.

IEA. 2007c. “CERT Strategic Plan 2007-2011.” OECD/IEA, Paris.

IEA. 2007d. CO2 Emissions from Fuel Combustion: Emissions of CO2, CH4, N2O, HFC, PFC, FS6, Vol 2007 release 01. Paris: OECD/IEA.

IEA. 2007e. International Standards to Develop and Promote Energy Efficiency and Renewable Energy Sources. Paris: OECD/IEA.

IEA. 2007f. "Energy Technologies on the Cutting Edge.” OECD/IEA, Paris.

IEA. 2008a. Energy Technology Perspectives 2008. Paris: OECD/IEA.

IEA. 2008b. Towards a Sustainable Energy Future: IEA Programme of Work on Climate Change, Clean Energy and Sustainable Development. Paris: OECD/IEA.

Jaffe, A.B., R.G. Newell, and R.N. Stavins. 2003. Technological change and the environment. In Handbook of Environmental Economics, Vol. 1, pp. 461-516. Edited by K.-G. Mäler and J. Vincent. Handbooks in Economics series, K.J. Arrow and M.D. Intriligator, series eds. Amsterdam: North-Holland/Elsevier.

Kortum, Samuel and Josh Lerner. 2000. Assessing the contribution of venture capital to innovation. RAND Journal of Economics 31(4): 674-692 .

Love, J. and T. Hubbard. 2007. The big idea: Prizes to stimulate R\&D for new medicines. Chicago-Kent Law Review 82(3):1519-1554.

METI (Ministry of Economy, Trade, and Industry). 2008. “Cool Earth: Innovative Energy Technology Program.” METI, Tokyo.

National Research Council. 2007. Innovation Inducement Prizes at the National Science Foundation. Washington, DC: National Academies Press.

National Science Board. 2008. Science and Engineering Indicators. Arlington, VA: National Science Foundation.

Newell, Richard G. 2007a. Climate technology research, development, and demonstration:

Funding sources, institutions, and instruments. Issue Brief 9 in Assessing U.S. Climate Policy Options, ed. Raymond J. Kopp and William A. Pizer. Resources for the Future, Washington, DC. 
Newell, Richard G. 2007b. Climate Technology Deployment Policy. Issue Brief 10 in Assessing U.S. Climate Policy Options, ed. Raymond J. Kopp and William A. Pizer. Resources for the Future, Washington, DC.

Newell, Richard G. 2008. “A U.S. Innovation Strategy for Climate Change Mitigation.” Discussion Paper 2008-15. Hamilton Project, Brookings Institution, Washington, DC.

Newell, R.G. and N. Wilson. 2005. Technology Prizes for Climate Mitigation. Discussion Paper 05-33. Resources for the Future, Washington, DC.

OECD (Organization for Economic Cooperation and Development). 2007. "Revised Council Recommendation on Common Approaches on the Environment and Officially Supported Export Credits.” TAD/ECG(2007)9. Working Party on Export Credits and Credit Guarantees, OECD, Paris.

OECD. 2008. Main Science and Technology Indicators. Paris: OECD.

Popp, David, Richard G. Newell, and Adam B. Jaffe. 2008. "Energy, the Environment, and Technological Change.” Manuscript in preparation for the Handbook of Economics of Technical Change. Oxford: Elsevier.

Reichman, Jerome, Arti K Rai, Richard G. Newell, and Jonathan B. Weiner. 2008. “Intellectual property and Alternatives: Strategies for a Green Revolution.” Energy, Environment, and Development Programme Paper 08/03. Chatham House, London, UK.

U.K. Department for Innovation, Universities and Skills. 2007. The 2007 R\&D Scoreboard. U.K. Department for Innovation, Universities and Skills: London.

UNEP (United Nations Environment Programme). 2008. Reforming Energy Subsidies: Opportunities to Contribute to the Climate Change Agenda. Geneva: UNEP.

UNEP and New Energy Finance. 2007. Global Trends in Sustainable Energy Investment 2007. Geneva: UNEP.

UNFCCC (United Nations Framework Convention on Climate Change). 2007a. Investment and Financial Flows to Address Climate Change. Bonn: UNFCCC.

UNFCCC. 2008. Report of the Conference of the Parties on its thirteenth session, held in Bali from 3 to 15 December 2007. Addendum. Part Two: Action taken by the Conference of the Parties at its thirteenth sessionBonn: UNFCCC.

USDOE (U.S. Department of Energy). 2006. U.S. Climate Change Technology Program Strategic Plan. Washington, DC: U.S DOE.

USCAP (U.S. Climate Action Partnership). 2007. A Call for Action. Washington, DC: USCAP.

Weyant, John P., Francisco C de la Chesnaye, and Geoff J. Blanford. 2006. Overview of EMF21: Multigas Mitigation and Climate Policy. Multi-Greenhouse Gas Mitigation and Climate Policy Special Issue. The Energy Journal.

World Bank. 2008a. “The Clean Technology Fund.” The World Bank, Washington, DC. 
World Bank. 2008b. “The Strategic Climate Fund.” The World Bank, Washington, DC.

World Bank. 2008c. Global Economic Prospects: Technology Diffusion in the Developing World. Washington, DC: The World Bank.

World Bank. 2008d. International Trade and Climate Change: Economic, Legal, and Institutional Perspectives. Washington, DC: The World Bank.

WIPO (World Intellectual Property Organization). 2008a. "Initial Working Document for the Committee on Development and Intellectual Property (CDIP)” WIPO, Geneva.

WIPO. 2008b. "Summary by the Chair, Committee on Development and Intellectual Property (CDIP) Second Session, July 7-11, 2008.” WIPO, Geneva.

Yang, C. and M. Oppenheimer. 2007. A "Manhattan Project” for climate Change? Climatic Change 80:199-204. 